DOI: $10.17805 /$ zpu.2016.4.24

\title{
Шекспиросфера в год четырехсотлетия бессмертия поэта*
}

\author{
B. C. МАКАРОВ
}

(ПРАВОСЛАВНЫЙ СВЯТО-ТИХОНОВСКИЙ ГУМАНИТАРНЫЙ УНИВЕРСИТЕТ, Г. МОСКВА),

Н. В. ЗАХАРОВ, Б. Н. ГАЙДИН

(МОСКОВСКИЙ ГУМАНИТАРНЫЙ УНИВЕРСИТЕТ)

В статье представлены некоторые итоги Всемирного года Шекспира, который в 2016 г. был посвящен 400-й годовщине памяти английского драматурга. Отмечены ключевые мероприятия уходящего года, дан обзор медийных событий и новых научных открытий, которые помогают определить место Шекспира среди констант мировой культуры, приблизиться к пониманию тайны непреходящей славы Великого Барда.

Ключевые слова: Шекспир; Год языка и литературы Великобритании и России; тезаурусный подход; константы культуры; вечные образы; шекспиросфера; шекспиризация; шекспиризм, шекспировская индустрия; неошекспиризация

\footnotetext{
* Статья подготовлена в рамках проекта «Виртуальная шекспиросфера: трансформации шекспировского мифа в современной культуре», поддержанного грантом РГНФ (№ 14-03-00552а).

The article was prepared as part of the project "Virtual Shakespearean Sphere: Transformations of Shakespearian Myth in Modern Culture" supported with a grant from the Russian Foundation for the Humanities (No. 14-03-00552a).
} 


\section{BВЕАЕНИЕ}

билейный 2016 год, как и ожидалось, был богат на шекспировские события. Что нового они принесли в наше понимание Шекспира и его место в мировой культуре - еще предстоит осознать. В этой статье мы предлагаем опыт критического осмысления шекспировского юбилея во всем его многообразииі.

\section{NONSANZDROICT!}

\section{СТЭНАИ УЭАИС УАОСТОЕН РЫЦАРСКОГО ЗВАНИЯ}

10 июня 2016 г. на сайте британского правительства был опубликован список представленных к королевским наградам за выдающиеся достижения. Такой документ публикуется два раза в год - в конце календарного года (New Year Honours) и в июне, перед официальным Анем рождения правящего монарха (Queen's Birthday Honours).

В июньском списке есть имя, дорогое для всех шекспироведов мира. Профессор Стэнли Уэллс, многолетний глава Шекспировского института, а ныне - почетный президент фонда «Аом-музей Шекспира» (Shakespeare Birthplace Trust), был удостоен рыцарского звания.

Стэнли Уильям Уэллс - один из самых известных ныне живущих шекспироведов, автор множества статей и книг (например, «Шекспир: на все времена» (Wells, 2003), «Шекспир и Ko» (Wells, 2006), «Шекспировский круг» (The Shakespeare circle, 2015) и мн. др.), главный редактор Оксфордского собрания сочинений Шекспира. В 2007 г. за заслуги в шекспироведении ученый стал Командором Ордена Британской империи. В кратком интервью ВВС Стэнли Уэллс высказал благодарность ученым всего мира, с которыми ему посчастливилось сотрудничать, и надежду на то, что все они разделят его радость.

18 ноября 2016 г. в Букингемском дворце состоялся обряд посвящения в рыцари профессора С. Уэллса. Церемонию проводил давний поклонник творчества Шекспира и покровитель Королевского театра принц Чарльз Уэльский.

Мы от всей души рады за СтэнлиУэллса, благодарны ему за сотрудничество и внимание к российским шекспировским проектам.

\section{ЧТО ЗНАЧИТ «ПОНИМАТЬ ШЕКСПИРА»?}

Наверное, в Великобритании не осталось крупной газеты или новостного агентства, которые не сообщили бы об итогах опроса, проведенного компанией YouGov по заказу Британского совета. Заголовки полны тревоги и самоуничижения: «Шекспир популярнее за рубежом, чем в Британии» (Brown, 2016: Электронный ресурс), «Четверо из десяти британцев не любят или не понимают Шекспира» (Furness, 2016: Электронный ресурс). «Аейли Мейл» цитирует шекспировского Антония: «УАар из всех ударов злейший...» (пер. М. А. Зенкевича; Rielly, 2016: Электронный ресурс).

Сюжет традиционен: ученик превзошел учителя, бывшие колонии и экономически зависимые территории перегоняют приходящую в упадок «порфироносную вдову» и т. д. Настолько ожидаемо традиционен, что очень интересно посмотреть - как же на самом деле построено это исследование.

Компания YouGov - одна из наиболее известных на британском поллстерском рынке (к слову, ее сооснователем и исполнительным директором является Стефан Шекспир (Stephan Shakespeare)). По заказу Британского совета компания провела уже не одно исследование; не первый опыт анализа общественного мнения это и для 
Аласдера Аоналдсона (Alasdair Donaldson). Итоговый текст появился на сайте под заголовком All the World's (Donaldson, 2016) - любопытно оборванная цитата из пьесы «Как вам это понравится».

Важнее всего в этом документе даже не собственно Шекспир, а идея «мягкой силы». Авторы теории «мягкой силы» и крупнейшие современные теоретики «комплексной взаимозависимости» в международных отношениях Роберт Киохан (Robert Keohane) и Ажозеф Най (Joseph Nye) проводят важное различие между «высокой» (собственно межгосударственные отношения) и «низкой политикой» (экономика, культура и все то, что связывает общества, а не правительства). Авторы исследования поставили цель именно выяснить, чем Шекспир может быть полезен для британской «мягкой силы», - с учетом того, что за рубежом его чаще считают символом Британии, чем королеву или «Битлз» (этими данными открывается основной текст исследования, см.: Ibid: 5).

Предисловие, написанное министром культуры и цифровой экономики Соединенного Королевства Эдом Вэйзи (Ed Vaize), тоже ловко соединяет политическое и культурное. Оно завершается фразой: «По словам самого Барда, “весь мир - театр”, и его собственное наследие помогает Британии блистать на мировой арене» (“In the words of the Bard himself, 'all the world's a stage', and his legacy helps Britain to shine in the global arena"; ibid: 2). Сцена шекспировского театра и подмостки мировой политики - эта метафора повторяется на сорока страницах доклада настолько часто, что кажется, авторы начинают верить: автор «Кориолана» уже давно поднимается на сцену именно как герой спектакля о «мягкой власти». Неоднозначно начинает звучать и само слово «роль», которую Шекспиру выпало сыграть в ее укреплении (“...the role hiswork can play to support the UK's soft power").

Этой же логике подчинен и выбор стран, в которых проводился опрос. Единый критерий не назван, но в двух разных фрагментах упоминаются страны, «экономически и стратегически важные для Соединенного Королевства» (“of significant economic and strategic importance to the UK"; ibid: 6) и обладающие «быстро растущей экономикой и возрастающим геополитическим влиянием» (“major high growth economies and places of increasing geopolitical influence...”; ibid: 3). Пример последних - Индия. Из стран Евросоюза присутствуют Франция и Германия, также опрос проводился в США, Австралии, Индии, Бразилии, Мексике, Турции, Китае, Гонконге, ЮАР, Южной Корее, Индонезии и Египте и в самой Великобритании. Всего в нем участвовало более 18000 человек (не менее 1000 в каждой из стран).

YouGov не дает детального описания опроса, ограничиваясь кратким указанием, что онлайн-опрос наиболее оптимален по соотношению цены и результата. Компания обычно проводит такие опросы на собственной платформе (в ее региональных локализациях). Респонденты - те, кто зарегистрирован на ней и получает баллы за участие в опросе. Скорее всего, не стал исключением и опрос о Шекспире. Если это так, то мы имеем дело с аудиторией, интересующейся культурой и общественной жизнью Британии (то есть несколько отличающейся от среднего показателя для своей страны). Авторы исследования это тоже понимают, но им не кажется, что это делает опрос менее репрезентативным: те, кто регистрируется на платформе YouGov, - будущие активные граждане, заинтересованные в развитии связей с Британией (“реорle who are more likely to be interested in and able to benefit from future international connections, and more likely to be current or future influencers and decision makers within their countries"; ibid: 38 ). 
Во все заголовки газет попало распределение ответов на первую группу вопросов - любят ли и понимают ли Шекспира респонденты, и согласны ли они, что его труды остаются важными для наших дней ("То what extent do you agree or disagree that you like Shakespeare, understand Shakespeare's work and find Shakespeare's work relevant today?"; ibid: 9).

Невозможно не заметить, что сама формулировка первой части вопроса содержит логическое противоречие. Как подтвердить понимание Шекспира? Что вообще значит «понимать Шекспира»? Аостаточно ли для этого посмотреть один-два фильма, прочитать один-два сонета или нужно более глубокое знакомство с его творчеством (насколько глубокое)? Опрос не дает основания для выводов, но приведенные в нем данные (где вновь смешаны англоязычные и неанглоязычные страны) показывают, что по частоте ассоциаций с именем драматурга с огромным отрывом дидирует трагедия «Ромео и Ажульетта», далее идут «Гамлет», «Макбет», «Король Аир», «Венецианский купец», «Сон в летнюю ночь», «Отелло», «Укрощение строптивой», «Как вам это понравится» (см.: Ibid: 18). Слова «сонет» среди самых частотных ассоциаций, как ни странно, нет.

Избежать такого противоречия можно было бы, если бы существовали единые критерии понимания. Но это невозможно в ситуации, когда «шекспировский опыт» респондентов настолько радикально отличается. В англоязычных странах практически все изучали Шекспира в школе, в отличие от респондентов из стран третьего мира. В англоязычных странах опыт «театрального Шекспира» накладывается на уже существующий опыт «школьного Шекспира», в Турции, Китае или Бразилии опыт «школьного Шекспира» может просто отсутствовать. В этом глубокая ошибка разработчиков опроса - ошибка, которая делает необратимо тенденциозной всю дальнейшую интерпретацию его результатов, настолько тенденциозной, что о «любви» и «понимании» в этом смысле просто не получается писать без кавычек.

Респондент, работающий с платформой британской компании, заинтересован в том, чтобы считать себя понимающим Шекспира, - даже не ради того, чтобы получить за это баллы, а потому что так крепче чувство причастности к «британскости». Показательно, что различие в числе «любящих» и «понимающих» Шекспира в Великобритании и остальных странах лежит почти в пределах статистической погрешности (59-65\% в вопросе о «любви» к Шекспиру, 58-59\% - в вопросе о понимании). Серьезные различия появляются, когда мы говорим о «нелюбви» $(34 \%$ респондентовбританцев и $19 \%$ в других странах) и «непонимании» (36\% и $25 \%$ соответственно). Как и следовало ожидать, британцы, имея более глубокий и разнообразный шекспировский опыт, сильно поляризованы в отношении к нему (всего $5 \%$ неопределившихся против $14 \%$ за рубежом).

Структура «любви» и «понимания» по странам почти неизменна: впереди Индия, Мексика, Бразилия, Турция и ЮАР (страны с более долгим и разнообразным опытом национальной адаптации Шекспира, где его «любят» 73-89\% респондентов, а «понимают» 71-83\%). Замыкают оба списка Гонконг, Индонезия, Франция и Германия, правда, в несколько разном порядке (44-55\% «любят» Шекспира и $39-47 \%$ его «понимают»). А. Аоналдсон прав в том, что эти результаты трудно возвести к единственной причине. Низкое положение Франции и Германии, вероятно, действительно можно объяснить тем, что респондентов из этих стран очень многое связывает с британской культурой, и для Шекспира здесь остается не так много места. Интересно, что Китай и по «любви», и по «пониманию» Шекспира значительно обгоняет Гонконг с его давней историей образования на английском языке. 
Напрашивается и традиционный вывод о том, что англоязычные респонденты вынуждены читать Шекспира на «архаичном» ранненовоанглийском, в то время как переводы обычно делаются на современный язык ("Shakespeare's relatively lower popularity in anglophone countries could therefore be partly related to the growing inaccessibility of his language to native English speakers"; ibid: 11). Однако Аоналдсон сам же отмечает, что в таком случае непонятно, почему множество современных переводов не помогают французам и немцам больше «любить» и «понимать» Шекспира.

К сожалению, журналисты, прочитав обобщенные результаты исследования на первых страницах, редко доходят до того этапа, когда авторы пытаются выяснить хотя бы какие-то детали о «шекспировском опыте» респондентов. Здесь - снова ошибочно противопоставляя не англоязычные и неанглоязычные страны, а Великобританию и все остальные - поллстеры наконец узнают, что 14\% респондентов-небританцев (и 6\% британцев) вообще не имеют никакого шекспировского опыта. Конечно, таких респондентов стоило бы сразу исключить из выборки. Всего $30 \%$ небританцев (разумеется, прежде всего американцы и австралийцы) изучали Шекспира в школе или вузе на английском языке (в Великобритании - 70\%; а почему бы, кстати, не спросить и про родной язык?). Относительно близки показатели только по вопросу о знакомстве с поэзией Шекспира (44\% небританцев и 54\% британцев) и среди тех, кто знает о Шекспире, но шекспировского опыта не имеет (9\% и 10\% соответственно).

Перед нами столь разительно несхожие траектории шекспировского опыта, что не стоило бы вообще объединять их в одном опросе. А авторы делают именно это, подходя к своей главной полемической цели - показать, что именно изучение Шекспира в школах и вузах делает его «нелюбимым» ("It is possible that teaching them academically might not always be the optimal way to introduce them to people; ibid: 3 ). Тут идут в ход все аргументы: истоки творчества Шекспира - в массовых празднествах ("...given that the origin of Shakespeare's plays was as popular entertainment..."; ibid), cam он не был «ученым» (вероятно, в том смысле, что не имел университетского образования) ("He was not a scholar producing erudite works in a now-distant and literary tradition"; ibid: 22) и т. А.

Эта искусственная дихотомия совершенно не оправдана исторически: Шекспир брал сюжеты и детали из книг, которые писали и читали «ученые» (от хроник Р. Холиншеда и Э. Холла до биографий Плутарха) и вносил в текст немало отсылок к малоизвестным в деталях массовому зрителю трудам - от Аристотеля до М. Монтеня. Но и это не подтверждает гипотезу, что во всем виновата система образования.

Отвечая на вопрос, какие факторы помогли им «полюбить» (или «не полюбить») Шекспира, респонденты на первые три места в обоих случаях поставили фильмы на шекспировские сюжеты, чтение поэзии Шекспира и изучение его на английском языке в школе или вузе (в последнем случае немногим более $40 \%$ считают это влияние положительным и чуть более $30 \%$ респондентов - отрицательным). Изучение Шекспира на родном языке (неанглийском) реже воспринимается как отрицательный фактор (чуть более $10 \%$ ), но реже - и как положительный (примерно 25\%). Изучать Шекспира на английском языке могли не более $40 \%$ всех респондентов (а смотреть фильмы и читать поэзию - все $100 \%$, так как в вопросе язык не указан), поэтому проблема не в низком проценте «полюбивших» Шекспира благодаря школьным урокам, а в относительно высоком проценте «не полюбивших» по этой причине.

Авторы исследования всеми силами подталкивают нас к выводу, что для многих приятнее и лучше смотреть фильмы и спектакли, чтобы «полюбить»и «понять» 
Шекспира ("Indeed, there is some evidence that people may appreciate Shakespeare's plays more when they watch stage or film adaptations than when they learn about them in school; ibid: 3). Все это сочетается с популярной среди «эффективных менеджеров» манерой говорить о культуре в терминах рынка: Шекспир - британский «актив» (“asset”) и «культурная продукция» (“cultural output”), которую «потребляют»во всем мире (ibid).

Но настоящий смысл исследования кроется в последней группе вопросов - о том, насколько Шекспир изменяет представление респондентов о Британии. Тут, конечно же, образование отходит на второй план (около $35 \%$ респондентов упомянули как положительный фактор изучение Шекспира на английском и примерно $30 \%$ - на родном языке, данные по Великобритании здесь исключены из выборки), зато крайне высока роль фильмов и поэзии. Причину этого понять нетрудно: образование на английском языке не сводится к изучению одного автора, да и странно делать выводы о современной Британии, читая Шекспира. Но для авторов все то, что заставляет лучше думать о Британии, априори прекрасно. Роль Шекспира как рыцаря «мягкой силы» на школьных подмостках незаметна? Или опять перепутан шекспировский опыт англоязычных и неанглоязычных респондентов?

Отвечая на последний вопрос, участники опроса предсказуемо указали, что их повысившееся (или понизившееся) мнение о Британии и ее культуре в первую очередь ( $70 \%$ или $60 \%$ в случае негативного ответа) порождает у них желание или нежелание посетить страну в качестве туриста. Правда, совершенно неясно, при чем тут Шекспир - разве не могло их отношение измениться под влиянием других факторов?

Хорошо и приятно ограничиваться фильмами, когда, в сущности, неважно, что и как будут знать о Шекспире и его текстах, главное, чтобы культурный герой покрепче ассоциировался с современной Британией. Конечно, есть в исследовании и брошенные мельком замечания о том, как, например, пьеса «Ромео и Ажульетта» способна помочь маргинализованным сообществам во всем мире (“Adaptations of Shakespeare's plays, and perhaps Romeo and Juliet in particular, have the potential to reach out to marginalised communities around the world...”; ibid: 20). Реплика совершенно верная, но в одном ряду с потребительской риторикой крайне неуместная. Маргинализованные группы в любом случае сделают Шекспира орудием борьбы за то, чтобы субалтерн смог заговорить. Им нужен свой Шекспир, культурно локализованный, но глобальный в социальном смысле. Попытка продать им британского «Барда» как кратчайший путь к туристической визе вряд ли вызовет у них понимание. Как, в общем-то, и вся стратегия апроприации Шекспира в пользу туристской индустрии.

Вполне возможно, что такая путаница в мотивациях британских и иностранных «потребителей» Шекспира вновь вызовет к жизни колониальный «эффект бумеранга», о котором писала Ханна Арендт (Hannah Arendt; см.: Arendt, 1951). Чтобы максимально увеличить культурную притягательность Великобритании, образовательный элемент (ведь он дал такую волну «нелюбви» к Шекспиру) в «мягкой силе» подавляется в пользу развлекательного. А потом бумеранг может ударить уже по изучению Шекспира в самой Англии и других англоязычных странах, ведь посмотреть фильм намного проще, чем прочитать пьесу и подумать над ней или поставить ее в школьном театре, или научиться видеть современные проблемы в оригинальном тексте XVI-XVII вв.

Чтобы избежать этого, необходимо серьезное и критическое исследование стратегий шекспировского опыта в разных странах, языковых и образовательных ситуаци- 
ях. С чего начинается знакомство с Шекспиром? На каком этапе наступает разочарование? Какими способами текст четырехсотлетней давности может быть связан с современностью и, в частности, с дичным опытом?.

Когда этот текст был уже написан, на сайте Бирмингемского университета появилась резко полемическая реплика директора Шекспировского института профессора Майкла Аобсона (Michael Dobson), озаглавленная «Шекспир - не национальный поэт» (Dobson, 2016: Электронный ресурс). Вывод Аобсона недвусмыслен - в текстах Шекспира нет ничего, что напрямую служило бы интересам правительственного Агентства по делам туризма и в целом современного британского государства ("...there is nothing in his plays and poems which lends itself directly to the purposes of either the English Tourist Board or the modern British state"; ibid).

М. Аобсон прав: Шекспир принадлежит не только своей эпохе, тем графствам и городам, где он жил и бывал, но и любым другим временам и регионам мира, где люди переживают опыт встречи с его творчеством. Все попытки сделать из него рупор общеизвестных истин терпят неудачу. Знаменитый монолог Гонта о величии Британии в «Ричарде II» звучит в момент, когда монархия крайне непрочна. О «порядке» в мире «Троила и Крессиды» рассказывает герой, наиболее склонный манипулировать «порядком» - Улисс. Аюбая пьеса в целом сложнее, глубже и многозначнее, чем любой отдельный ее фрагмент или монолог. Точно так же, полагает Аобсон, и сам Шекспир сразу «перерос» рамки Англии, и не случайно история «европейских» и «мировых Шекспиров» началась еще при его жизни - в Германии и Польше, где его пьесы ставили труппы странствующих актеров.

Эта реплика директора Шекспировского института очень важна. Нередко даже на конференциях слышны упреки, что Шекспир «слишком британский», что британские литературоведы монополизируют право на Шекспира, превращают себя в оракулов «Барда». Если бы это действительно было так, британским ученым было бы очень удобно присоединиться к глашатаям «мягкой силы»: да, Шекспир - наше национальное достояние, приезжайте к нам поклониться и причаститься его мощи. Ничего подобного: изучение «мировых Шекспиров» стало одним из основных направлений в современной науке, и это подтверждают такие издания, как недавно вышедший в свет двухтомный «Кембриджский путеводитель по мирам Шекспира»- его второй том полностью посвящен «шекспировскому опыту» в культурах всего мира (The Cambridge Guide ... , 2016; см. также: Захаров, 2015).

Не может быть единого «понимания» Шекспира, он принадлежит всем, и всем поразному. Исследователи - филологи, историки, театроведы и многие другие, - подобно шекспировскому Пэку (или Ариэлю, если более возвышенный образ вам приятнее), мгновенно преодолевают разрывы времени и пространства, переходя от одного шекспировского опыта к другому, но сам этот опыт доступен каждому из нас. Шекспиросфера - это не только вечные образы и герои, это также и стратегии превращения их сценического опыта в наш повседневный (см.: Аисович, Макаров, 2014).

Конечно, все это верно для любого автора, не только для Шекспира. Но без уникального опыта глобальной шекспиросферы мы вряд ли бы это поняли.

\section{ШЕКСПИР И ЦИФРОВЫЕ ТЕХНОАОГИИ}

\section{«Эвристический Шекспир»}

Английский актер театра и кино сэр Иэн МакКеллен (Ian McKellen), известный по ролям в кинотрилогиях «Властелин колец» и «Хоббит» (Гәндальф) и в фильмах «Аю- 
ди Икс» (Магнето), заслужил признание, выступая в Королевской шекспировской компании (Royal Shakespeare Company) в 1970-1980-х годах. За свою долгую карьеру он сыграл в более чем 50 шекспировских постановках, а с 1977 по 1990 г. колесил по миру со своим театральным шоу «Играя Шекспира» (Acting Shakespeare), моноспектаклем с актерскими комментариями. Маккеллен также прославился ролями в пьесах современников Шекспира (Бен Ажонсон, Кристофер Марло и Ажон Форд).

Истинный мастер шекспировского репертуара, МакКеллен не смог отказаться от предложения, поступившего от Heuristic Media - компании-разработчика приложений для iPad. Совместными усилиями было создано первое из серии мобильных приложений, которые призваны сделать пьесы Шекспира более доступными и понятными для современных школьников и студентов. Как объяснил сам МакКеллен, изначально пьесы Шекспира предназначались для просмотра вживую в театре, а не для чтения. Этот крупнобюджетный международный проект «Эвристический Шекспир» (Heuristic Shakespeare) позволяет совместить видео с исполняющим драматические сцены из пьесы актером и текст, который можно прокручивать по ходу действия.

Всего планируется запустить 37 таких приложений - по количеству пьес официально признанного шекспировского канона. Первое приложение посвящено «Буре», одной из поздних шекспировских пьес, которой также открывается Первое фолио. Его стоимость на iTunes на момент подготовки данной статьи составила 459 руб. Коллега МакКеллена, хорошо известный в России по телевизионным сериалам «Шерлок», «Пустая корона» (The Hollow Crown, BBC, 2016) и недавней роли Гамлета, исполненной им в лондонском театре «Барбикан», Бенедикт Камбербэтч (Benedict Cumberbatch) уже успел оценить разработку.

Приложение включает: полный текст «Бури» по Первому фолио; полную цифровую версию «Бури» по изданию в серии The Arden Shakespeare; возможность выбора трех уровней примечаний и научного комментария в зависимости от потребностей читателя; полную характеристику каждого персонажа пьесы и отдельно все его реплики по сценам; хронологию жизни Шекспира, его пьес, современного ему театра, что позволит пользователю лучше понять шекспировскую эпоху; видео, в которых сэр Иэн МакКеллен и профессор Ажонатан Бейт (Jonathan Bate) поясняют и обсуждают героев, символы, темы и смыслы пьес; режим “play-at-a-glance” (иллюстрации, краткое изложение сюжета, ключевые цитаты и события произведения); историю основных постановок «Бури» с XVII века и до наших дней; возможность делать заметки, копировать и выделять фрагменты текста, которые можно сопоставить друг с другом или экспортировать в другие приложения; возможность поиска по полному тексту и справочным материалам.

\section{Изучение английского языка через жизнь и творчество У. Шекспира}

11 января 2016 г. при поддержке Британского совета и при участии фонда "Аоммузей Шекспира» (Shakespeare Birthplace Trust) стартовал очередной бесплатный шекспировский массовый открытый онлайн-курс на платформе FutureLearn «Изучение английского языка: Шекспир» (Exploring English: Shakespeare). Авторский курс Энтони Косгроува (Anthony Cosgrove) посвящен жизни и творчеству У. Шекспира и охватывает период от его рождения в провинциальном городке Стратфорд-на-Эйвоне до его актерской и драматургической деятельности в знаменитом лондонском театре «Глобус». Упор сделан на актуальности изучения произведений Шекспира, 
ибо считается, что именно он придумал более 1000 английских фраз и слов, которые до сих пор используются в повседневной речи. Курс призван поведать о значении языкового наследия, оставленного Шекспиром.

Автор курса Э. Косгроув является разработчиком учебных пособий и материалов по английскому языку для Британского совета и Университета Саутгемптона. В разные годы он жил и работал в Польше и Индии. Среди разработанных им курсов «Изучение английского языка: Великая хартия вольностей»; «Профессиональные практики преподавания английского языка»; «Изучение английского: языка и культуры»; «Понимание теста IELTS: методики тестов на знание английского языка»; «Понимание языка: изучение и обучение» и др.

Слушателям курса предлагалось прочитать и изучить пять наиболее популярных пьес Шекспира: «Ромео и Ажульетта», «Гамлет», «Много шума из ничего», «Буря» и «Макбет». На помощь Э. Косгроуву пришли актеры из Королевского шекспировского театра и исследователи творчества Шекспира из разных стран. Они помогли понять универсальный характер наследия драматурга, раскрыли мотивы, образы, к которым обращался Шекспир.

С помощью видеороликов кураторы курса наглядно показали те слова и выражения, которые Шекспир ввел в английский язык. Как это принято в формате МООК, каждый смог проверить усвоение нового материала при помощи тестовых вопросов и поделиться мнением о произведениях Шекспира с другими участниками курса.

Курс предназначен для всех, интересующихся наследием У. Шекспира и изучающих английский язык как иностранный. В нем используются учебные материалы Британского совета, ориентированные на уровень Intermediate или B1 по шкале CEFR. Курс предложил гибкий график обучения, который требовал около двух часов занятий в неделю. Приступить к занятиям можно было с любого технического устройства (ноутбук, планшет или мобильный телефон) в любое удобное время. Алительность курса - 6 недель.

\section{"Hamlet's Ghost":}

\section{МOOK С. Гринблатта о Призраке в шекспировском «Гамлете»}

Осенью 2016 г. курсом “Наmlet's Ghost” в мир МООКов вошел профессор кафедры гуманитарных наук имени Ажона Когана Гарвардского университета Стивен Гринблатт (Stephen Jay Greenblatt). Казалось бы, участием крупнейших мировых шекспироведов в массовых открытых онлайн-курсах уже никого не удивишь: на британской платформе Future Learn уже не первый год идут курсы, авторами которых стали директор Шекспировского института М. Аобсон и профессор Оксфорда сэр Аж. Бейт. Не отстают от Future Learn и американские платформы - EdX и Coursera. B последнее время часто пишут, что МООКи выдыхаются, что их авторам (по крайней мере в гуманитарных науках) удаются лишь обзорные курсы, но не посвященные конкретной проблематике. Интересным ответом на этот вызов может стать курс о Призраке в шекспировском «Гамлете», с которым на $\mathrm{EdX}$ дебютировал Гринблатт.

С. Гринблатт - один из самых известных современных литературоведов, основоположник «нового историзма», лауреат Пулитцеровской премии и престижной Премии Хольберга, которую считают эквивалентом Нобелевской премии для гуманитарных наук. Шекспиром он занимается всю жизнь - в его самой известной ранней книге «Формирование “я” в эпоху Ренессанса: от Мора до Шекспира» (Greenblatt, 1980; фрагмент в русском переводе был опубликован в журнале «Новое литературное обо- 
зрение»: Гринблатт, 1999) без анализа шекспировских текстов обходятся только первые несколько глав. В 1980-е гг. «новый историзм» и шекспироведение нельзя было себе представить без его работы «Шекспировские негоциации: циркуляция социальной энергии в Англии эпохи Ренессанса» (Greenblatt, 1988). На рубеже нового тысячелетия Гринблатт по-новому объяснил проблематику «Гамлета» в связи с полемикой вокруг представлений о чистилище («Гамлет в чистилище» (Greenblatt, 2002)). Через несколько лет вышла в свет одна из лучших современных биографий английского драматурга - «Уилл в мире: как Шекспир стал Шекспиром» (Greenblatt, 2004), а в 2010 г. переработанная версия мемориальных адорновских лекций Гринблатта во Франкфуртском университете (под названием «Свобода Шекспира» (Greenblatt, 2010)).

Аля философии и в целом культуры XX века призрак Гамлета-старшего стал символом исторической памяти, зов которой одновременно притягивает и отталкивает (здесь можно вспомнить книгу о «Гамлете» Карла Шмитта (Schmitt, 2009) или обращение Жака Аеррида к «призракам Маркса» в одноименной книге (Аеррида, 2006)). Проблема веры или недоверия словам Призрака теперь считается одной из центральных в шекспировской трагедии.

Конечно, американец С. Гринблатт даже не пытается соревноваться со своими британскими коллегами и украшать свои видеолекции артефактами из богатейшей коллекции музейных сокровищ шекспировской эпохи. Но он прекрасно справляется и без них: лекции сняты на фоне реконструированного театра «Глобус» в $\Lambda$ ондоне, рядом с домом Шекспира в Стратфорде, в церкви First Parish в Кембридже (штат Массачусетс, США), на кладбище рядом с этим приходом и в других местах. Тезаурус этого курса находится за пределами материального мира, и это понятно, так как речь в нем идет о духовной стороне и смыслах трагедии потери отца, любви, о своей собственной судьбе и невыносимой боли утраты.

Как и в некоторых других МООКах, автор привлекает к диалогу экспертов для более глубокого раскрытия темы смерти - например, знатока мира мертвых, похоронных обрядов, верований и суеверий, известного историка из Калифорнийского университета Беркли профессора Томаса $\Lambda$ акера (Thomas Laqueur) или одного из авторов книги «Шекспир мертв» (Palfrey, Smith, 2016), преподавателя английской литературы в Оксфордском университете и крупнейшего специалиста по Первому фолио Эмму Смит (Emma Smith).

Соответственно, сложной стала и структура МООКа, который начал работу в понедельник, 31 октября 2016 г. Первая его часть посвящена театральным воплощениям Призрака и его месту в структуре первого акта трагедии. Во второй части участники курса погрузились в мир противоречивых представлений об аде, чистилище и рае в Евpoпе XVI-XVII вв., а в третьей - продолжили изучение шекспировской трагедии самостоятельно.

Курс неожиданно короток для МООКа - всего 3 недели, но затратен по времени (6-8 часов работы каждую неделю). Впрочем, слушатели могут изучать материал в удобном для них ритме (self-paced). Кроме традиционных видеолекций, материалов для самостоятельного изучения, чтения трагедии, письменных заданий и контрольных работ, курс «Призрак Гамлета» выгодно отличается доступностью всех материалов: можно бесплатно скачать все видеофайлы с лекциями и транскрипты текстов. Такой подход делает курс привлекательным и доступным, а сохраненные на компьютере материалы можно неоднократно использовать в образовательной практике в любое время. 
В интервью The Harvard Crimson C. Гринблатт рассказал, что началась работа над вторым гарвардским МООКом о Шекспире. Он будет посвящен «Венецианскому купцу» и ХОтелло» (см.: Neckermann, 2016: Электронный ресурс).

\section{МАРАО, ШЕКСПИР И НОВОЕ ОКСФОРАСКОЕ СОБРАНИЕ СОЧИНЕНИЙ HА ПААТФОРМЕ OSEO}

Версия о том, что Кристофер Марло не был убит в Аептфорде 30 мая 1593 г., а скрылся во Франции и Италии и там продолжил сочинять свои пьесы, которые переправлял на родину под псевдонимом «Шекспир», довольно давно будоражит умы исследователей «шекспировского вопроса». В 1819 г. анонимный автор предположил, что «Кристофер Марло» - псевдоним Шекспира. В конце XIX - первой половине $\mathrm{XX}$ в. появился целый ряд работ, предлагающих «марловианское» решение проблемы авторства шекспировских произведений. В 1955 г. вышла книга американского журналиста и театрального критика Кальвина Гофмана (Calvin Hoffman) «Человек, бывший Шекспиром» (Hoffman, 1955), в которой это точка зрения получила наиболее подробное изложение, а аргументация построена на примерах сходства между стилями Марло и Шекспира. Это мнение разделял, к примеру, российский и японский литературовед и философ А. А. Ванновский (см.: Ульянов, 1998). В 1994 г. вышла работа «История, которую рассказывают сонеты» (Walker-Wraight, 1994) британской писательницы А. А. Уолкер-Рейт (A. D. Walker-Wraight), которая предложила свои доказательства того, что именно Марло скрывался за «маской» Шекспира-актера, проанализировав шекспировские сонеты. В 2001 г. австралийский кинорежиссер Майкл Раббо (Michael Rubbo) выпустил телевизионный фильм «Много шума по существу» (Much Ado About Something), в котором также подробно изложены аргументы марловианцев. Наконец, в 2009 г. было создано Международное марловианско-шекспировское общество (International Marlowe-Shakespeare Society), члены которого пытаются поощрять появление новых исследований этого вопроса.

Однако среди большинства ведущих шекспироведов и специалистов по творчеству Марло эта теория не сыскала широкой поддержки, поскольку сложно себе представить, что «тайна Марло» хотя бы раз в виде слуха не нашла отражение в дневниках и литературных произведениях тех лет. Более того, как отмечает С. Уэллс в своей книге «Шекспир и $\mathrm{K}^{0}$ », нет никаких оснований сомневаться в подлинности официальных документов, подтверждающих трагическую гибель Марло в доме на Аептфордстренд (Wells, 2006: 100).

Как бы то ни было, 23 октября 2016 г. газета «Гардиан» сообщила, что в Новом оксфордском собрании сочинений Шекспира (The New Oxford Shakespeare), которое вышло в свет в ноябре - декабре этого года, на всех трех частях исторической хроники «Генрих VI» (1591) появится и имя Кристофера Марло. Команда из 26 экспертов из пяти стран пришла к выводу, что именно он был соавтором Шекспира при создании этой драматической трилогии. По мнению исследователей, Марло принадлежит большая часть первой части «Генриха VI», а Шекспиру - основная часть третьей части (Alberge, 2016: Электронный ресурс).

Ученые проанализировали тексты шекспировских пьес, применив проверенные временем текстологические методы и самые последние компьютерные технологии, и сошлись во мнении, что Шекспир сотрудничал со своими собратьями по перу гораздо более часто, чем считалось до этого. Сразу в 17 пьесах они обнаружили следы совместной работы Шекспира и других драматургов - его современников. Таким обра- 
зом, количество пьес, написанных драматургом в соавторстве, увеличилось более чем в два раза, если сравнивать их с числом, указанным в оксфордском издании, вышедшем 30 лет назад.

Руку Марло в трех частях хроники «Генрих VI» находили еще в XVIII столетии, однако впервые он указан в качестве соавтора в столь авторитетном издании. Главными редакторами данного собрания сочинений выступили Гари Тейлор (Gary Taylor; Государственный университет Флориды, США), Ажон Ажоуэтт (John Jowett; Шекспировский институт Бирмингемского университета, Великобритания), Терри Боурус (Terri Bourus; Университет Индианы, Индианаполис, США) и Габриэль Игэн (Gabriel Egan; Университет Ае Монфор, Аейстер, Великобритания).

Интересно, что когда в 1986 г. редакторы Оксфордского собрания сочинений Шекспира объявили, что 8 из 39 пьес Шекспир написал в соавторстве с другими драматургами, это вызвало шквал критики. Остается только догадываться, сколько негативных и положительных рецензий получит новое издание Оксфордского университета, в котором опубликованы уже 44 пьесы.

Из новых открытий отметим также появление имени Томаса Мидлтона в качестве соавтора пьесы «Все хорошо, что хорошо кончается». По мнению ученых, в пьесе можно обнаружить «шекспировский слой», который был создан примерно в 1605 г. и «мидлтоновский слой», который драматург добавил уже после смерти Шекспира, в 1620-х годах. Из апокрифов, впервые включенных в собрание сочинений, - пьеса «Арден из Фавершама» (Arden of Faversham), опубликованная анонимно в 1592 г. По мнению шекспироведов, она была написана неким пока неизвестным автором (но точно не Кристофером Марло и не Томасом Кидом) и Шекспиром.

Как и обещали редакторы Нового оксфордского собрания сочинений Шекспира, первыми доступ к электронной версии этого издания получают пользователи Охford Scholarly Editions (OSEO: www.oxfordscholarlyeditions.com). Мы уже писали об этой уникальной платформе незадолго до ее запуска (Макаров, 2012: Электронный ресурс). Впервые столь крупное издательство отказалось от идеи работать исключительно с библиотеками и открыло доступ к академическим изданиям классических текстов английской литературы - от Скелтона до Аиккенса - индивидуальным подписчикам.

Сейчас на платформе OSEO (включая и оксфордские издания классиков древнеримской литературы) - более 20 модулей, построенных по принципу эпохи и рода литературы. У такого построения есть и свои недостатки - так, первый том сочинений Кристофера Марло, включающий его поэмы и стихотворные переводы, отнесен к «Поэзии Возрождения», а остальные - к «Араме Возрождения». Схожим образом разделены тома сочинений Роберта Грина, Ажона Аили, Ажона Аонна и Бена Ажонсона. Продавать доступ к двухтомному собранию пьес и стихотворений Грина под редакцией Ажона Чёртона Коллинза, которое вышло еще в 1905 г. (Greene, 1905), — не самая честная стратегия (учитывая, что на Archive.org его можно скачать бесплатно). Но тем не менее OSEO - единственный, не считая библиотек, способ для читателей всего мира (кроме Северной и Южной Америки) легально пользоваться академическими оксфордскими изданиями английских классиков.

В электронной версии каждого издания текст и комментарии выведены в разные фреймы на одном экране и связаны якорными ссылками для более удобного просмотра. Можно скачивать файлы в формате PDF, причем как электронный вариант, так и отсканированные страницы оригинального издания (в последнем случае - постранично, в первом - по разделам книги). 
Но вернемся к Шекспиру. Пока на платформе появилось только «современное» издание (Modern Critical Edition) - в него вошли только сами тексты пьес, краткий словарный комментарий и небольшие вступительные справки о пьесах. В декабре 2016 г. должно стать доступным более полное «справочное» (Critical Reference Edition) с подробным текстуальным комментарием и в оригинальной орфографии. Наконец, в январе 2017 г. появится и долгожданная электронная версия «справочника по шекспировскому авторству» (Authorship Companion), в котором авторы подробно рассказывают о стилометрических методах и доказанных случаях соавторства.

Впрочем, о структуре издания можно судить уже и по «современной» версии The New Oxford Shakespeare. Произведения выстроены в условно хронологическом порядке, в ущерб традиционной «жанровой» структуре, а иногда и вопреки удобству чтения (например, вторая и третья часть «Генриха VI» расположены раньше первой).

В предисловии под названием «Зачем читать именно это Полное собрание сочинений?» Г. Тейлор и Т. Боурус объясняют, что такая логика помогает увидеть связь между «творческой биографией» Шекспира (“a biography of his creativity”) и «микроисторией театра и поэзии» шекспировской Англии (“Вut it also situates his work within the micro-history of theatre and poetry in his lifetime"; см.: Taylor, Bourus, 2016a: 48).

Каждому тексту предшествует «бриколаж»- набор цитат и мнений критиков, литературоведов, режиссеров и т. А., в нарочито произвольном порядке (например, бриколаж к утраченному «Карденио» начинается с цитаты из Эдмунда Гейтона, который в 1654 г. назвал Аон Кихота «Шекспиром из [ $\Lambda$ a] Манчи», а далее следуют отрывки из работ Роже Шартье и Стивена Гринблатта). Бриколаж должен привлечь к пьесе внимание читателя, особенно такого, который склонен пролистывать малоизвестные пьесы, поэтому среди мнений попадаются и скандально критические, и неумеренно восторженные - не включены дишь те, которые могут оставить читателя равнодушным.

Узнать многое о пьесе в «современном» издании не получится. Справки о каждом тексте - "Background" - занимают иногда менее одной страницы и построены по жесткому плану: роли - дата сочинения - сценическая история - первые публикации текста - временная шкала, в которую включены даты исторических событий, выхода в свет источников шекспировского текста и т. А.

Оригинально и деление пьес на акты и сцены - редакторы оставляют его только там, где оно оправдано логикой пьесы, и потому его можно считать частью авторского замысла (в целом начиная только с 1600-х годов, почти все более ранние пьесы печатаются в разбивке на отдельные сцены).

Открывается издание «Авумя веронцами» - самой ранней пьесой $(1587$, возможно, с переработками в 1590 -е и начале 1600 -х годов), к которой приложил руку Шекспир. За ней следуют «Тит Андроник» (1589-1590) и две последние части «Генриха VI» (1590 и 1591 соответственно). Таким образом, от «темного» периода в биографии Шекспира почти ничего не остается: если принять, что Шекспир переехал из Стратфорда в $\Lambda$ ондон в середине 1580-х годов, то он, согласно редакторам The New Oxford Shakespeare, практически сразу стал работать над текстами пьес, и в дальнейшем эта работа не прерывалась. Заполнить временные лакуны раннего и позднего периодов помогают вновь введенные в канон пьесы: «Арден из Фэйвершема» (ок. 1588), «Эдуард III» (1592), «Карденио» (1612), «Ава благородных родича» (1613). После «Бури» (1611), которую в такой хронологии трудно считать «поэтическим завещанием» 
Шекспира, - еще два года работы в соавторстве с Ажоном Флетчером. Написанные совместно с другими драматургами пьесы не сосредоточены только в самом начале и конце работы Шекспира-драматурга, а повторяются регулярно (дополнения к «Испанской трагедии» Томаса Кида (1599), возможное участие в «Сеяне» Бена Ажонсона (1601), фрагмент «Томаса Мора» (1601-1602) и т. А.). Такая хронологическая реконструкция подчеркивает, что совместное авторство - постоянная шекспировская практика (впрочем, это верно и для его коллег). Эта версия канона, конечно, интереснее, чем попытки приписать Шекспиру многие пьесы 1580 -х - начала 1590-х годов и бесконечные переработки якобы собственных более ранних текстов, как это, например, делал Эрик Самс (Sams, 1995).

Общая концепция нового издания подробнее объяснена в еще одном предисловии «Зачем читать Полное собрание сочинений Шекспира?» (Taylor, Bourus, 2016b). Это довольно непростой текст, хотя он и рассчитан на «нефилологического» читателя.

Аля нового издания, рассчитанного (в этой версии) на читателя, прежде всего погруженного в современную культуру, нужна новая метафора Шекспира и шекспировского творчества. Метафору, которая связала бы огромные пласты работы литературоведов, историков, театроведов и исследователей современной культуры, ищут уже давно. В сущности, «шекспиросфера» нашего проекта - один из вариантов этой метафоры.

Задача состоит в том, чтобы не утратить общее пространство, в котором на общем языке смогут говорить о Шекспире как академические ученые, так и актеры, режиссеры и все вовлеченные в мир современной культуры. «Культ Барда» (см., например:

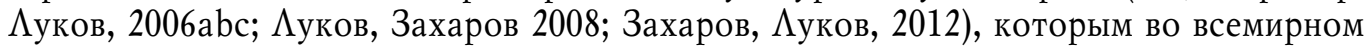
масштабе якобы управляет кучка академических «стратфордианцев», существовал только в воспаленном сознании отрицателей Шекспира. Сейчас мы скорее наблюдаем Аругой процесс - с научными центрами начинают конкурировать театры. В «Шекспировском глобусе», например, существует своя научная и образовательная программа (вплоть до подготовки аспирантов совместно с лондонским Кингс-колледжем) и это помогло по-новому поставить темы исследований, например, изучать сценическую историю шекспировских пьес, на которую у академического литературоведения часто не хватало внимания.

Но любые институции (как, например, показала недавняя история конфликта между Эммой Райс и руководством «Шекспировского глобуса») очень быстро ограничивают разнообразие подходов и практик. На этом пути нас может поджидать новая ортодоксия: «Шекспир», мол, живет только в постановках и интерпретациях, поэтому то, что происходит сейчас на сцене или на экране, важнее и интереснее, чем история текстов XVI-XVII вв. Конечно, шекспировед и одновременно театральный критик - фигура более медийная, чем просто академический шекспировед. Но опыт The New Oxford Shakespeare показывает, что «незаметная» текстологическая работа сейчас важна нисколько не менее, чем раньше. Открытие в шекспировских пьесах пластов текста, написанных другими авторами (и наоборот!) показывает, что мы, в сущности, еще мало знаем Шекспира, еще только преодолеваем представление о колоссальной фигуре «Барда», затмившей для нас всех его современников.

Поэтому любой опыт поиска объединяющей метафоры очень полезен - иначе не станет единого шекспироведческого поля. Редакторы The New Oxford Shakespeare говорят, например, о шекспировской «нейронной сети», которая связывает историю и современность: "Every writer who writes about Shakespeare, positively or negatively, 
expands the neural net that connects Shakespeare to our culture. Those who complain about his work only stimulate more connections" (Taylor, Bourus, 2016b: 18). Еще одна метафора - комната, в которой Шекспира, как Элвиса, уже нет, но через нее проходит бесконечный поток спорящих о нем и с ним: "Shakespeare has left the room; he has been dead for hundreds of years. But in the room Shakespeare vacated so long ago generations of men and women come and go, still in conversations with and about him, naming him, arguing about him, quoting him" (ibid: 19). Шекспир оставил нам «инфраструктуру воображения» (“imaginative infrastructure first built by Shakespeare”; ibid: 30), которая помогает строить по его образцу и перестраивать сделанное им. Конечно, все «элементы» этой постройки, к какому бы периоду истории они ни относились, в нашем распоряжении сейчас как фрагменты, отобранные для бриколажей «современного» издания. Аргументацию Гамлета в одном из эпизодов авторы предисловия сравнивают с речами диккенсовского Скруджа, гонителей театров XVII в., современного «менеджера хедж-фонда» или чиновника министерства финансов - и все это через запятую.

И все же самая важная и часто повторяющаяся в предисловии метафора - это «виртуальные миры», которые создает Шекспир; параллельные вселенные, о которых как будто бы одновременно думают современные астрофизики, авторы ренессансных поэтик и Ажордано Бруно. «Полное собрание сочинений», считают редакторы, можно было бы назвать «полным собранием игр»: "Perhaps we should call this book 'William Shakespeare: The Complete Games'. Shakespeare is something we play. His Complete Works is an anthology of extraordinarily powerful and varied virtual reality game worlds" (ibid: 33). Виртуальный мир выдуман - но так же сконструированы и все человеческие сообщества (редакторы очень уместно сводят в одном предложении монолог шекспировского Жака о мире-театре и книгу Бенедикта Андерсона «Воображаемые сообщества» (Андерсон, 2001)). Виртуальный мир подчиняет человека собственной логике, заставляя его, как в тренажерном зале, тренировать любопытство и эмпатию. Наконец, виртуальный мир проводит человека через остранение и тем самым расширяет наше понимание человеческого: “...becoming alien, expanding our definition of what it can mean to be human, helping us to imagine what it would be like to live hundreds of different lives in dozens of different social universes" (Taylor, Bourus, 2016b: 33).

Если метафора «виртуальных миров» действительно может задать поле, на котором найдется место для шекспироведов-теоретиков и практиков, для них, возможно, нужно именно такое издание - в нескольких версиях, «навынос», одним словом, как иронично замечают сами авторы предисловия, «тапас-Шекспир» (Tayloretal., 2016: iv). Но все-таки точнее еще одна метафора (и ее редакторы тоже приводят) - та, которой С. Уэллс завершает книгу «Шекспир на все времена»: «Он - в нашем водопроводе, и останется там, пока вода в трубах не иссякнет» ("Не is in the water supply, and is likely to remain there until the pipes run dry"; Wells, 2003: 403).

Таким образом, все чаще гипотезы о том, что Шекспир творил в сотрудничестве с другими авторами своей эпохи, находят свое эмпирическое подтверждение. Это, на наш взгляд, еще один аргумент в пользу того, что только человек, живший непосредственно в «котле» лондонского театрального мира, мог написать пьесы, ставшие впоследствии классикой мировой драматургии. 


\section{НОВЫЕ КНИГИ И ПЕРЕВОАЫ \\ Журнах «Иностранная литература»: \\ «И снова БарА...: к 400-летию со Аня смерти Шекспира»}

1 июня 2016 г. в культурном центре «Покровские ворота» (Москва, ул. Покровка, А. 27, стр. 1) прошла презентация пятого номера журнала «Иностранная литература» за 2016 год - номера, целиком посвященного 400-летию со дня смерти Шекспира. В отличие от такого же тематического номера двухлетней давности, этот номер посвящен не столько «беспокойному бессмертию» Шекспира, сколько Шекспиру историческому и тому, какие представления о нем стоило бы скорректировать.

Открыли презентацию выступления составителей номера - Т. Я. Казавчинской и А. А. Иванова. Они представили разделы журнала, посвященные поэтике Шекспира в ее историческом формировании. Здесь прежде всего стоит отметить выполненный А. А. Ивановым перевод нескольких глав из книги лекций Клайва Стейплза Иьюиса (Clive Staples Lewis) «Английская литература XVI века, за исключением драмы» (Иьюис K., 2016). Несмотря на то что книга $\Lambda$ ьюиса, как нам кажется, во многом устарела, перевод прекрасно задает общую концепцию номера - уточнить наши представления об историческом Шекспире, в частности показать, что уравнивать всю английскую литературу XVI века с философией гуманизма неверно.

В номере хорошо представлены «гранды» современного шекспироведения С. Гринблатт (Гринблатт, 2016), Аж. Бейт (Бейт, 2016аb) и М. Аобсон (Аобсон, 2016). Также очень интересен подготовленный Т. Я. Казавчинской раздел об исторических и политических аллюзиях в пьесах Шекспира, прежде всего о макиавеллизме и героях«макиавелях» (переводы отрывков из работ Аоминик Го-Бланке (Dominique GoyBlanquet; Го-Бланке, 2016), Уоррена Чернейка (Warren Chernaik; Чернейк, 2016), Аэвида Хёрли (David Hurley; Хёрли, 2016), Ажона Алана Poy (John Alan Roe; Poy, 2016),

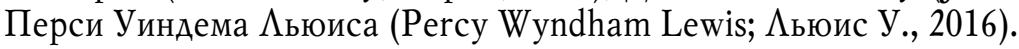

Поэт и филолог А. В. Нестеров рассказал о том, какую роль в политической, экономической и литературной жизни эпохи сыграл сэр Уолтер Рэли (Sir Walter Raleigh; см.: Остер, 2016), а также представил перевод писем «о нашем дорогом Гамлете» уренса Ааррелла (Lawrence Durrell; Ааррелл, 2016), адресованных Генри Миллеру (Henry Miller). Стихотворения Томаса Венцловы (Tomas Venclova; см.: Венцлова, 2016) и Збигнева Херберта (Zbigniew Herbert) на сюжет «Гамлета» прочитала Е. А. Нестерова, а свою знаменитую «Корделию» и перевод послания сәра Ажона Аенема (Sir John Denham) Ричарду Фэншо (Richard Fanshawe) - M. Я. Бородицкая. «Гамлетовский» раздел завершил режиссер В. Р. Поплавский, представивший небольшое эссе о жанре «Гамлета» в отечественных постановках второй половины XX века (Поплавский, 2016).

М. С. Гринберг рассказал о работе над переводами шекспировских эссе Ива Бонфуа (Yves Bonnefoy; см.: Бонфуа, 2016), а поэт и переводчик В. А. Куллэ - о своем видении датировки и структуры шекспировских сонетов.

В заключение были представлены два новых издательских проекта - Полное собрание сочинений Шекспира (под редакцией С. А. Радлова, проект Университетского издательского консорциума, Санкт-Петербург; см.: Радлов, 2016) и «режиссерские версии» «Ричарда II» и «Гамлета», подготовленные группой энтузиастов во главе с А. М. Королевой (Москва; см.: Иванов, 2016). С. Б. Иихачева прочитала отрывки из своего перевода пьесы Шекспира и Ажона Флетчера (John Fletcher) «Ава благородных родича», который выполнен для проекта Полного собрания сочинений. 
Несомненно, номер «Иностранки», озаглавленный «И снова Бард...: К 400-летию со дня смерти Шекспира», стал событием для шекспироведов и всех интересующихся творчеством великого драматурга. Не все материалы, подготовленные для номера, удалось в него включить. Составители обещали, как и в 2014 г., публиковать их в остальных номерах 2016 г. в рубрике «Год Шекспира» и сделали это. В № 10 были опубликованы эссе «Письмо Шекспиру» британской писательницы и литературного критика Хилари Мантел (Hilary Mantel; Мантел, 2016), шекспировская поэма «Венера и Адонис» (Шекспир, 2016а) в переводе В. А. Куллэ, статья «Разгадка Гамлета лингвиста и литературоведа А. К. Жолковского (Жолковский, 2016), интервью с британским актером и режиссером Кеннетом Браной (Kenneth Branagh) под названием «Beликий датчанин» (Мейзер, 2016), а также отрывок из поэмы Хаима Плуцика (Нуат Plutzik) «Горацио» (Плуцик, 2016).

\section{Переводы А. А. Корчевского}

В журнале «Современная драматургия (№ 3 2016) был опубликован перевод пьесы «Авойное вероломство, или Влюбленные в беде» (Double Falsehood, or The Distressed Lovers), выполненный А. А. Корчевским (Шекспир, Флетчер, 2016). Как известно, «Авойное вероломство» было представлено публике 13 декабря 1727 г. на сце-

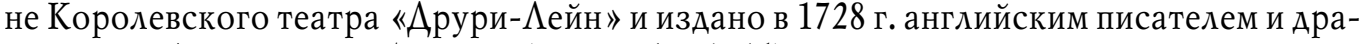
матургом $\Lambda$ ьюисом Теобальдом (Lewis Theobald), который утверждал, что восстановил его на основе трех рукописей некой утерянной пьесы У. Шекспира. Проблема ее авторства с самого начала вызвала ожесточенные споры. В 2010 г. было издано комментированное издание «Авойного вероломства» в серии The Arden Shakespeare. В последние годы появились несколько работ, авторы которых вновь обращаются к этому вопросу и доказывают, что пьеса была написана Шекспиром (первые три акта) и Ажоном Флетчером (последние два), полагая, что $\Lambda$. Теобальд действительно только немного адаптировал найденные им рукописные варианты утерянной пьесы «История Карденио» (The History of Cardenio; 1612-1613). (См., например: The quest for Cardenio ... , 2012; The creation and re-creation of Cardenio ... , 2013; Tarlinskaja, 2014). Это первый перевод «Авойного вероломства» на русский язык. Предисловие к переводу написал известный специалист по этой таинственной «утерянной пьесе» почетный профессор Ноттингемского университета Брин Хэммонд (Brean Hammond, Великобритания).

В издательстве «Текст» был опубликован перевод Первого кварто «Гамлета», выполненный А. А. Корчевским (Шекспир, 2016b; о переводе см.: Корчевский, 2015ab; Баранов, 2015)ii.

\section{«Фантастический Шекспир»}

В издательстве «Шико-Севастополь» вышел из печати сборник «Фантастический Шекспир» (Фантастический Шекспир, 2016), где опубликованы художественные произведения, в которых Шекспир и его герои попадают в новые миры фантазии и воображения: стихи «Антреприза. Четыре века спустя» С. Битюцкого, повести «Сон в апрельскую ночь» Жаклин де Гё, «Сельгонский континуум» М. Савеличева, «Расскажи это Шекспиру!» М. Фороста, «Аттилио» А. Сибгатуллина. В сборнике также можно ознакомиться со статьями «Пятьдесят оттенков Шекспира. Введение в игру» В. Балашовой и «Реквием каравану “Армада” А. Володихина. 


\section{Академическое Авуязычное издание «Сонетов»}

В издательстве «Наука» в серии «Иитературные памятники» вышло новое издание шекспировских «Сонетов», приуроченное к Году английского языка в России и 400-летию со дня смерти У. Шекспира (Шекспир, 2016с). В книге представлены текст оригинала (по изданию: Shakespeare, 2002), а также полные русскоязычные переводы всего цикла, выполненные М. И. Чайковским, С. Я. Маршаком, А. М. Финкелем, Игн. М. Ивановским и В. Б. Микушевичем. В разделе «Аополнения» также представлены избранные переводы сонетов Шекспира XIX-XX вв. других переводчиков (А. В. Аверкиева, И. М. Астерман, В. Г. Бенедиктова, Б. В. Бера, В. Я. Брюсова, Н. А. Брянского, А. Г. Васильчикова, Р. И. Винонена, Н. В. Гербеля, И. А. Гриневской, Н. С. Гумилева, С. А. Ильина, А. Б. Казаковой, П. М. Карпа, П. Н. Краснова, Г. М. Кружкова, А. И. Кузнецова, Б. А. Кушнера, А. С. Аибермана, В. С. Аихачева, Ю. И. Аифшица, В. А. Мазуркевича, И. А. Мамуны, А. Ю. Милитарева, В. В. Набокова, В.А. Николаева, В. Э. Орла, И. А. Оськина, Б. А. Пастернака, В. Ф. Перелешина, В. Р. Поплавского, В. К. Розова, О. Б. Румера, К. К. Случевского, С. А. Степанова, А. И. Уманца, Н. А. Холодковского, А. М. Федорова, Е. А. Фельдмана, В. С. Флоровой, К. М. Фофанова, И. З. Фрадкина, Ф. А. Червинского, И. Е. Чупис, А. М. Штыпеля, А. В. Щедровицкого, Т. А. Щепкиной-Куперник).

Издание оснащено новыми примечаниями, подготовленными кандидатом филологических наук, доцентом кафедры германской филологии Православного Свято-Тихоновского гуманитарного университета (г. Москва) В. С. Макаровым. В них кроме уже известных любителям творчества поэта точек зрения представлены и самые последние открытия специалистов, занимающихся проблематикой шекспировских сонетов. Известный отечественный дитературовед, доктор филологических наук, профессор Московского государственного университета им. М. В. Аомоносова А. Н. Горбунов подготовил статью «Сонеты Шекспира: загадки и гипотезы», в которой охарактеризовал историю создания сонетов Шекспира в контексте сонетной культуры XVI-XVII вв., а также различные тайны и загадки, не дающие покоя исследователям при прочтении поэзии Шекспира и его современников. Кандидат философских наук, доцент кафедры философии Московского педагогического государственного университета В. С. Флорова в статье «Основные тенденции и подходы к изучению сонетов Шекспира в английской критике XVII-XX веков» осветила текстологические проблемы изучения сонетов, а также историю их рецепции на родине Барда и в других странах мира за четыре столетия. Аоктор филологических наук, профессор кафедры русского языка как иностранного Аальневосточного федерального университета (г. Владивосток) Е. А. Первушина в статье «"Но смерть поправ, до будущих времен дойдет мой стих...” (Сонеты Шекспира в русских переводах)» представила историю и характерные черты отечественной сонетианы с середины XIX столетия и до нашего времени. В работе «Сонетные вставки в пьесах Шекспира» доктора филологических наук, $\mathrm{PhD}$, старшего научного сотрудника Отдела классических литератур Запада и сравнительного литературоведения Института мировой литературы им. А. М. Горького РАН Е. В. Халтрин-Халтуриной рассмотрены и проанализированы сонеты, которые можно обнаружить в текстах шекспировских пьес. Книга посвящена памяти Ирины Степановны Приходько, которая стала инициатором подготовки данного билингвального комментированного издания шекспировских «Сонетов». Работа была выполнена при поддержке РГНФ (проект «В. Шекспир. Сонеты. Подготовка текстологического, историко-литературного и поэтологического комментария», грант № 14-04-00531a). 


\section{УТРАТЫ}

К сожалению, Год Шекспира принес не только радость академического общения, просмотра новых постановок и экранизаций, чтения новых книг и статей. Он унес несколько замечательных людей, чья жизнь была связана с представлением Шекспира на сцене и в книге.

16 августа 2016 г. в Санкт-Петербурге на 85 -м году жизни ушел из жизни замечательный поэт-переводчик Игнатий Михайлович Ивановский. В его переводческой деятельности Шекспир занимает одно из центральных мест. Ему принадлежит перевод всего цикла шекспировских сонетов, который он посвятил памяти своего учителя

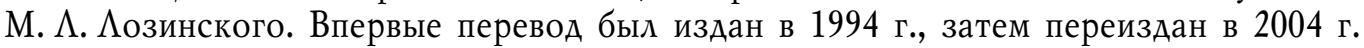
Особый интерес представляет его пьеса «Сонеты Шекспира», «ставшая блистательно ярким примером творческой игры Ивановского художественными смыслами шекспировских стихов» (Первушина, 2016: Электронный ресурс). В 2016 г., уже после смерти автора, его перевод вышел в академическом издании «Сонетов» в серии « $\Lambda$ итературные памятники», о котором мы рассказали выше. Это еще раз свидетельствуют о признании высокого переводческого таланта мастера и о том, что его переводы будут жить.

За две недели до открытия Международной научной конференции «Шекспировские чтения 2016: 400 лет бессмертия поэта» трагически погиб Аенис Козлов, актер театра и кино, сыгравший роль Гамлета в постановке В. Р. Поплавского, которую преАставлял на предыдущих «Шекспировских чтениях» осенью 2014 года коллектив театра-студии «Горизонт» Московского городского дома учителя. Аенис ушел из жизни в 32 года - почти гамлетовском возрасте. Он находился на подъеме своих творческих возможностей, с упоением играл свою любимую роль - Андрея Колычева в исторической драме А. Н. Островского «Василиса Мелентьева», мечтал о Макбете, в новом сезоне должен был выступить в образе Яго в осенней премьере «Отелло». Этого не случилось. Запомним Аениса Козлова таким, каким он был в самой главной роли мирового репертуара - в роли принца Аатского.

6 декабря 2016 г. безвременно ушел из жизни известный актер, театральный педагог, художественный руководитель и главный режиссер Московского театра на ЮгоЗападе, народный артист России Валерий Романович Белякович. Среди режиссерских работ В. Р. Беляковича особое место занимают спектакли по произведениям У. Шекспира: в Театре на Юго-Западе - «Гамлет» (1-я редакция - 1984, 2-я редакция 2003), где он играл роль Клавдия; «Укрощение строптивой» $(1992,2008)$; «Ромео и Ажульетта» (1992); «Макбет» (1994); «Сон в летнюю ночь» (1996); «Ааешь Шекспира!» (2003); в театре «Тоуэн» (Токио) - «Ромео и Ажульетта» (1993); в Пензенском областном драматическом театре имени А. В. Ауначарского - «Ромео и Ажульетта» (1994, 2014); «Сон в летнюю ночь» (1997); «Укрощение строптивой» (1998); в театре «Комедія» (Нижний Новгород) - «Сон в летнюю ночь» (2000) и «Ааешь Шекспира!» (2004); в театре «Арт-Сфера» (Токио) — «Гамлет» (2003); в театре «Пикколо» (Амагасаки) - «Гамлет» (2007); в Московском художественном академическом театре имени им. М. Горького - «Сон в летнюю ночь» (2008). В 2010 г. за цикл спектаклей «Шекспир на рубеже веков» артист был удостоен премии Правительства Российской Федерации в области культуры. В 2010 г. он принял участие в Международной научной конференции «Шекспировские чтения» (Москва, 26-30 сентября). Актер поделился своими воспоминаниями об А. А. Аниксте, 100 -летию со дня рождения которого была посвящена конференция, а также прочитал стихотворение, написанное шек- 
спироведом на фронте. Вклад В. Р. Беляковича в мировую шекспириану еще только предстоит осмыслить.

\section{ПРИМЕЧАНИЯ}

i Начало обзора см.: Захаров, Гайдин, Макаров, 2016.

iі Перевод был впервые опубликован в журнале «Современная драматургия» в 2015 г. (Шекспир, 2015). Он был обсужден на Втором заседании Международного научного семинара «Шекспир в междисциплинарных гуманитарных исследованиях» 15 октября 2015 г. (о семинаре см.: Макаров, Захаров, Гайдин, 2015: Электронный ресурс; Шекспир в междисциплинарных ..., 2015). 23 ноября 2016 г. во Всероссийской государственной библиотеке иностранной литературы имени М. И. Рудомино А. А. Корчевский представил новое издание своего перевода Первого кварто «Гамлета», осуществленное издательством «Текст».

\section{ЗАКАЮЧЕНИЕ}

Формат статьи не позволяет нам охватить сразу все интересные и важные события, в которых нашли отражение шекспировское наследие и сам драматург спустя четыре столетия после своей смерти. В следующей статье мы осветим шекспировские конференции, лекции и фестивали, состоявшиеся в 2016 г. в России и мире, а также представим более подробные итоги нашего исследования шекспиросферы.

\section{СПИСОК АИТЕРАТУРЫ}

Андерсон, Б. (2001) Воображаемые сообщества. Размышления об истоках и распространении национализма / пер. В. Николаева ; вступ. ст. С. Баньковской. М. : КАНОН-пресс-Ц ; Кучково поле. 288 с.

Баранов, А. Н. (2015) О переводе Первого кварто «Гамлета», сделанном А. А. Корчевским // Шекспир в междисциплинарных гуманитарных исследованиях : коллективная монография по материалам Международного научного семинара / ред.-сост. В. С. Макаров, Н. В. Захаров, Б. Н. Гайдин. М. : Изд-во Моск. гуманит. ун-та. 238 с. С. 78-89.

Бейт, Аж. (2016а) Стратфордская грамматическая школа (глава из книги «Ауша века»)/ пер. А. Б. Сумм // Иностранная литература. № 5. С. 36-47.

Бейт, Аж. (2016b) Шекспир на рубеже тысячелетий (заключительная глава книги «Гений Шекспира») / пер. Е. М.Аоброхотовой-Майковой // Иностранная литература. №5. C. 207-219.

Бонфуа, И. (2016) Интервью и два рассказа на тему «Гамлета» / пер. М. С. Гринберга // Иностранная литература. №5. С. 124-137.

Венцлова, Т. (2016) Скажите Фортинбрасу : стихотворение / пер. Г. И. Ефремова // Иностранная литература. №5. С. 163.

Го-Бланке, А. (2016) Елизаветинская историография и шекспировские источники : фрагмент статьи / пер. и вступл. Т. Я. Казавчинской // Иностранная литература. № 5. С. 68-71.

Гринблатт, С. (1999) Формирование «я» в эпоху Ренессанса: от Мора до Шекспира (главы из книги) / пер. Г. М. Аашевского // Новое литературное обозрение. № 35. С. 34-77.

Гринблатт, С. (2016) Шекспир и Монтень / пер. Е. А. Суриц // Иностранная литература. № 5. C. 51-60.

Ааррелл, $\Lambda .(2016)$ «О нашем дорогом Гамлете...» : из писем Аоуренса Ааррелла Генри Миллеру / пер. и вступл. А. В. Нестерова // Иностранная литература. №5. С. 138-145.

Аеррида, Ж. (2006) Призраки Маркса. М. : Logos-altera ; Ecce homo. 256 с.

Аобсон, М. (2016) Шекспир и идея национальных театров / пер. Е. Ю. Калявиной // Иностранная литература. №5. С. 106-120.

Жолковский, А. К. (2016) Разгадка Гамлета // Иностранная литература. № 10. С. 158-173. 
Захаров, Н. В. (2015) Кембриджский гид к всемирному Шекспиру // Научные труды Московского гуманитарного университета. № 1. C. 75-83. DOI: $10.17805 /$ trudy.2015.1.12

Захаров, Н. В., Гайдин, Б. Н., Макаров, В. С. (2016) Всемирный год Шекспира - 400 лет бессмертия поэта // Знание. Понимание. Умение. № 2. С. 287-306. DOI: 10.17805/zpu.2016.2.26

Захаров, Н. В., Ауков, Вл. А. (2012) Гений на века: Шекспир в европейской культуре : научная монография. М. : ГИТР. 504 с.

Иванов, А. А. (2016) «Гамлет»: режиссерская версия / А. А. Иванов (корр.), А. М. Королева // Иностранная литература. № 5. С. 276-283

Корчевский, А. А. (2015а) О новом переводе Первого кварто «Гамлета» // Шекспир в междисциплинарных гуманитарных исследованиях : коллективная монография по материалам Международного научного семинара / ред.-сост. В. С. Макаров, Н. В. Захаров, Б. Н. Гайдин. М. : Изд-во Моск. гуманит. ун-та. 238 с. С. 68-78.

Корчевский, А. А. (2015b) «Знакомо и неожиданно»// Современная драматургия. №3. C. 210.

Иисович, И. И., Макаров, В. С. (2014) Научно-исследовательский проект «Виртуальная шекспиросфера: трансформации шекспировского мифа в современной культуре»// Знание. Понимание. Умение. № 2. С. 264-282.

Ауков, Вл. А. (2006а) Культ Шекспира: введение в исследование // Шекспировские штудии II: «Русский Шекспир» : исследования и материалы науч. семинара, 26 апреля 2006 г. М. : Изд-во Моск. гуманит. ун-та. С. 3-11.

Иуков, Вл. А. (2006b) Культ Шекспира: тезаурусный анализ понятия // Иитература Великобритании и романский мир : тезисы докладов Междунар. науч. конференции и XVI съезда англистов 19-22 сентября 2006 г. Великий Новгород. С. 81-82.

Ауков, Вл. А. (2006с) Культ Шекспира как научная проблема // Вестник Международной академии наук (Русская секция). № 2. С. 70-72.

Ауков, Вл. А., Захаров, Н. В. (2008) Культ Шекспира // Знание. Понимание. Умение. № 1. C. $132-141$.

Аьюис, К. С. (2016) Новое знание и новое невежество (из книги «Английская литература XVI века, за исключением драмы») / пер. А. А. Иванова // Иностранная литература. №5. C. 6-35.

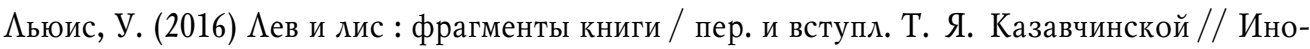
странная литература. №5. С. 84-90.

Макаров, В. С. (2012) Уникальный проект Oxford University Press [Электронный ресурс]// Информационно-исследовательская база данных «Современники Шекспира». 20 февраля. URL: http://around-shake.ru/news/3764.htm (дата обращения: 30.11.2016).

Макаров, В. С., Захаров, Н. В., Гайдин, Б. Н. (2015) Шекспир в междисциплинарных гуманитарных исследованиях: итоги первого года семинара [Электронный ресурс] // Информационный гуманитарный портал «Знание. Понимание. Умение». № 6 (ноябрь-декабрь). С. 38-55. URL: http://zpu-journal.ru/e-zpu/2015/6/Makarov_Zakharov_Gaydin_Shakespeare-InterdisciplinaryHumanities-Research/(дата обращения: 30.11.2016).

Мантел, Х. (2016) Письмо Шекспиру / пер. Т. Я. Казавчинской // Иностранная литература. № 10. С. 136-137.

Мейзер, К. (2016) Великий датчанин : с Кеннетом Браной беседует Керри Мейзер / К. Мейзер (корр.), К. Брана ; пер. Е. Малышевой // Иностранная литература. № 10. С. 174-179.

Остер, П. (2016) Смерть сэра Уолтера Рэли : рассказ / пер. и вступ. А. В. Нестерова // Иностранная литература. №5. С. 61-67.

Первушина, Е. А. (2016) Памяти Игнатия Михайловича Ивановского [Электронный ресурс]// Информационно-исследовательская база данных «Русский Шекспир». 7 октября. URL: http:// rus-shake.ru/menu/news/14055.html (дата обращения: 30.11.2016).

Плуцик, X. (2016) Горацио : поэма (Глава V. Карл : отрывок)/ пер. и вступл. А. В. Нестерова // Иностранная литература. № 10. С. 180-186. 
Поплавский, В. Р. (2016) Жанр шекспировского «Гамлета» в российских постановках второй половины XX века // Иностранная литература. № 5. С. 158-162.

Радлов, С. А. (2016) О Полном собрании сочинений Шекспира : проект Университетского издательского консорциума, Санкт-Петербург // Иностранная литература. №5. С. 284-300.

Роу, А. (2016) Шекспир и Макиавелли : фрагмент книги / пер. Т. Я. Казавчинской // Иностранная литература. №5. С. 96-105.

Ульянов, Н. (1998) Новый Гамлет // Знание - сила. № 2. С. 148-152.

Фантастический Шекспир (2016) : сборник / сост. В. Балашова, под ред. А. Володихина. Севастополь : Шико-Севастополь. 182 с. (Серия «Антология МиФа»).

Хёрли, А. (2016) Макиавелли и его идеи в пьесах Шекспира : фрагменты лекции, прочитанной в Хиросиме, апрель 2009 / пер. Т. Я. Казавчинской // Иностранная литература. №5. C. 91-95.

Чернейк, У. (2016) Вступление к историческим пьесам Шекспира : фрагменты книги / пер. Т. Я. Казавчинской // Иностранная литература. №5. С. 72-83.

Шекспир в междисциплинарных гуманитарных исследованиях (2015) : коллективная монография по материалам Международного научного семинара / ред.-сост. В. С. Макаров, Н. В. Захаров, Б. Н. Гайдин. М. : Изд-во Моск. гуманит. ун-та. 238 с.

Шекспир, У. (2015) Трагическая история Гамлета, принца Аатского. Первое кварто / пер. А. А. Корчевского // Современная драматургия. № 3. С. 211-234.

Шекспир, У. (2016а) Венера и Адонис : поэма : с параллельным английским текстом / пер. В. А. Куллэ // Иностранная литература. № 10. С. 138-157.

Шекспир, У. (2016b) Трагическая история Гамлета, принца Аатского. Первое кварто (1603) / пер. и предисл. А. А. Корчевского, послесл. М. А. Аитвиновой. М. : Текст. 272 с.

Шекспир, У. (2016с) Сонеты / изд. подгот. А. Н. Горбунов, В. С. Макаров, Е. А. Первушина, В. С. Флорова, Е. В. Халтрин-Халтурина ; отв. ред. А. Н. Горбунов. М. : Наука. (Аитературные памятники).

Шекспир, У., Флетчер, Аж. (2016) Авойное вероломство, или Влюбленные в беде : в редакции Аьюиса Теобальда / пер. А. А. Корчевского // Современнаядраматургия. № 3. С. 212-235.

Alberge, D. (2016) Christopher Marlowe credited as one of Shakespeare's co-writers [Электронныйресурс] // The Guardian. October 23. URL: https://theguardian.com/culture/2016/oct/23/ christopher-marlowe-credited-as-one-of-shakespeares-co-writers(дата обращения: 30.11.2016).

Arendt, H. (1951) The origins of totalitarianism. N. Y. : Harcourt, Brace and Co. xv, 477 p.

Brown, M. (2016) Shakespeare more popular abroad than in Britain, study finds [Электронный pecypc] // The Guardian. April 19. URL: https://theguardian.com/culture/2016/apr/19/shakespeare-popular-china-mexico-turkey-than-uk-british-council-survey (дата обращения: 30.11.2016).

Dobson, M. (2016) Shakespeare, not the national poet [Электронныйресурс] // University of Birmingham. URL: http://birmingham.ac.uk/research/perspective/shakespeare.aspx (дата обращения: 30.11.2016).

Donaldson, A. (2016) All the world's: How Shakespeare is viewed around the globe and the role his work can play to support the UK's soft power / ed. by M. Lotten. S. n. : British Council. 41 p.

Furness, H. (2016) Four in ten Brits don't like or understand Shakespeare [Электронныйресурс]// The Telegraph. April 19. URL: http://telegraph.co.uk/news/2016/04/18/four-in-ten-brits-dont-likeor-understand-shakespeare/ (дата обращения: 30.11.2016).

Greenblatt, S. (1980) Renaissance self-fashioning: From More to Shakespeare. Chicago : University of Chicago Press. 321 p.

Greenblatt, S. (1988) Shakespearean negotiations: The circulation of social energy in Renaissance England. Berkeley, CA : University of California Press. xi, 205 p.

Greenblatt, S. (2002) Hamlet in purgatory. Princeton, NJ : Princeton University Press. xii, 322 p.

Greenblatt, S. (2004) Will in the world: How Shakespeare became Shakespeare. N. Y. : W. W. Norton. 430 p.

Greenblatt, S. (2010) Shakespeare's freedom. Chicago ; L. : The University of Chicago Press. xiii, 144 p. 
Greene, R. (1905) The plays \& poems of Robert Greene : in 2 vols. / ed., with introductions and notes, by J. Churton Collins. Oxford : Clarendon Press.

Hoffman, C. (1955) The man who was Shakespeare. L. : M. Parrish. 256 p.

Neckermann, C. N. (2016) Spooky Shakespeare HarvardX course debuts on Halloween [Электронный ресурс] // The Harvard Crimson. URL: https://thecrimson.com/article/2016/10/31/ shakespeare-harvardx-hamlet-course-debut/ (дата обращения: 30.11.2016).

Palfrey, S., Smith, E. (2016) Shakespeare's dead. Oxford : Bodleian Library. 191 p.

Rielly, B. (2016) The unkindest cut? Shakespeare more popular abroad than in Britain [Электронный ресурс] // Daily Mail Online. April 19. URL: http://dailymail.co.uk/wires/reuters/article-3547902/The-unkindest-cut-Shakespeare-popular-abroad-Britain.html (дата обращения: 30.11.2016).

Sams, E. (1995) The real Shakespeare: Retrieving the early years, 1564-1594. New Haven, CT : Yale University Press. xvi, 256 p.

Schmitt, C. (2009) Hamlet or Hecuba: The intrusion of the time into the play. N. Y. : Telos Press Publishing. li, 119 p.

Shakespeare, W. (2002) The complete sonnets and poems / ed. by. C. Burrow. Oxford ; N. Y. : Oxford University Press. ix, 750 p. (Oxford World's Classics).

Tarlinskaja, M. (2014) Shakespeare and the versification of English drama, 1561-1642. Farnham, Surrey ; Burlington, VT : Ashgate. x, 411 p.

Taylor, G. (2016) General editors' preface / G. Taylor, J. Jowett, T. Bourus, G. Egan// The New Oxford Shakespeare. Modern Critical Edition : The Complete Works / ed. by G. Taylor, J. Jowett, T. Bourus, G. Egan. Oxford University Press. P. iv-vi.

Taylor, G., Bourus, T. (2016a) Why read this complete works? // The New Oxford Shakespeare. Modern Critical Edition: The Complete Works / ed. by G. Taylor, J. Jowett, T. Bourus, G. Egan. Oxford University Press. P. 45-58.

Taylor, G., Bourus, T. (2016b) Why read Shakespeare's complete works? // The New Oxford Shakespeare. Modern Critical Edition : The Complete Works / ed. by G. Taylor, J. Jowett, T. Bourus, G. Egan. Oxford University Press. P. 1-44.

The Cambridge guide to the worlds of Shakespeare (2016) : in 2 vols. / ed. by B. R. Smith, K. Rowe. N. Y. : Cambridge University Press. Vol. 2: The world's Shakespeare, 1660 - present. xvii, 998 p.

The creation and re-creation of Cardenio: Performing Shakespeare, transforming Cervantes (2013) / ed. by T. Bourus, G. Taylor. N. Y. : Palgrave Macmillan. xviii, 329 p.

The quest for Cardenio: Shakespeare, Fletcher, Cervantes, and the lost play (2012) / ed. by D. Carnegie, G. Taylor. Oxford : Oxford University Press.xiv, 420 p.

The Shakespeare circle: An alternative biography (2015) / ed. by P. Edmondson, S. Wells. Cambridge : Cambridge University Press. ix, 358 p.

Walker-Wraight, A. D. (1994) The story that the sonnets tell. L. : Adam Hart. vi, 585 p.

Wells, S. (2003) Shakespeare: For all time. Oxford ; N. Y. : Oxford University Press. xxi, 442 p.

Wells, S. (2006) Shakespeare \& Co. : Christopher Marlowe, Thomas Dekker, Ben Johnson, Thomas Middleton, John Fletcher and the other players in his story. L. : Allen Lane. xv, 285 p.

Aата поступления: 7.12.2016.

THE SHAKESPEAREAN SPHERE

IN THE YEAR OFTHE 4OOTH ANNIVERSARY OF POET'S IMMORTALITY

V. S. MAKAROV

(ST. TIKHON'S ORTHODOX UNIVERSITY, MOSCOW),

N. V. ZAKHAROV, B. N. GAYDIN

(MOSCOW UNIVERSITY FOR THE HUMANITIES),

The article presents some results of the GlobalYear of Shakespeare dedicated to the 400th anniversary of the English playwright's death. The authors describe some key Shakespearean events of 2016, 
give a survey of media facts and new research discoveries which help determine the place of Shakespeare asa constant of world culture and come closer to the understanding of the enigma of the imperishable fame of the Great Bard.

Keywords: Shakespeare; UK-Russia Year of Language and Literature; thesaurus approach; cultural constants; constants of culture; eternal images; iconic characters; Shakespearean sphere; Shakespearisation; Shakespearianism; Shakespeare industry; neo-Shakespearisation

\section{REFERENCES}

Anderson, B. (2001) Voobrazhaemye soobshchestva. Razmyshleniia ob istokakb $i$ rasprostranenii natsionalizma / transl. by V. Nikolaev; introduction by S. Bankovskaia. Moscow, KANON-press-Ts Publ. ; Kuchkovo pole Publ. 288 p. (In Russ.)

Baranov, A. N. (2015) O perevode Pervogo kvarto «Gamleta», sdelannom A. A. Korchevskim. In: Shekspir $v$ mezhdistsiplinarnykh gumanitarnykh issledovaniiakb : A monograph based on the proceedings of the International research seminar / ed. and comp. by V. S. Makarov, N. V. Zakharov and B. N. Gaydin. Moscow, Moscow University for the Humanities Publ. 238 p. Pp. 78-89. (In Russ.)

Bate, J. (2016a) Stratfordskaia grammaticheskaia shkola (glava iz knigi «Dusha veka») / transl. by L. B. Summ. Inostrannaia literatura, no. 5, pp. 36-47. (In Russ.)

Bate, J. (2016b) Shekspir na rubezhe tysiacheletii (zakliuchitel'naia glava knigi «Genii Shekspira») / transl. by E. M. Dobrokhotova-Maikova. Inostrannaia literatura, no. 5, pp. 207-219. (In Russ.)

Bonnefoy, Y. (2016) Interv'iu i dva rasskaza na temu «Gamleta»/ transl. by M. S. Grinberg. Inostrannaia literatura, no. 5, pp. 124-137. (In Russ.)

Venclova, T. (2016) Skazhite Fortinbrasu : stikhotvorenie / transl. by G. I. Efremov. Inostrannaia literatura, no. 5, pp. 163. (In Russ.)

Goy-Blanquet, D. (2016) Elizavetinskaia istoriografiia i shekspirovskie istochniki : fragment stat'i / transl. and introduction by T. Ya. Kazavchinskaia. Inostrannaia literatura, no. 5, pp. 68-71. (In Russ.)

Greenblatt, S. (1999) Formirovanie «ia»v epokhu Renessansa: ot Mora do Shekspira (glavy iz knigi) / transl. by G. M. Dashevskii. Novoe literaturnoe obozrenie, no. 35, pp. 34-77. (In Russ.)

Greenblatt, S. (2016) Shekspir i Monten' / transl. by E. A. Surits. Inostrannaia literatura, no. 5, pp. 51-60. (In Russ.)

Durrell, L. (2016) «O nashem dorogom Gamlete...» : iz pisem Lourensa Darrella Genri Milleru / transl. and introduction by A. V. Nesterov. Inostrannaia literatura, no. 5, pp. 138-145. (In Russ.) Russ.)

Derrida, J. (2006) Prizraki Marksa. Moscow, Logos-altera Publ. ; Ecce homo Publ. 256 p. (In

Dobson, M. (2016) Shekspir i ideia natsional'nykh teatrov / transl. by E. Yu. Kaliavina. Inostrannaia literatura, no. 5, pp. 106-120. (In Russ.)

Zholkovskii, A. K. (2016) Razgadka Gamleta. Inostrannaia literatura, no. 10, pp. 158-173. (In Russ.)

Zakharov, N. V. (2015) Kembridzhskii gid k vsemirnomu Shekspiru. Naucbnye trudy Moskovskogo gumanitarnogo universiteta, no. 1, pp. 75-83. DOI: 10.17805/trudy.2015.1.12 (In Russ.)

Zakharov, N. V., Gaydin, B. N. and Makarov, V. S. (2016) Vsemirnyi god Shekspira - 400 let bessmertiia poeta. Znanie. Ponimanie. Umenie, no. 2, pp. 287-306. DOI: 10.17805/zpu.2016.2.26 (In Russ.)

Zakharov, N. V. and Lukov, Vl. A. (2012) Genii na veka: Shekspirv evropeiskoi kul'ture: A monograph. Moscow, Humanities Institute of TV \& Radio Broadcasting Publ. 504 p. (In Russ.)

Ivanov, D. A. (2016) «Gamlet»: rezhisserskaia versiia / D. A. Ivanov (corr.), A. M. Koroleva. Inostrannaia literatura, no. 5, pp. 276-283. (In Russ.)

Korchevskiy, A. A. (2015) O novom perevode Pervogo kvarto «Gamleta». In: Shekspir $v$ mezhdistsiplinarnykh gumanitarnykb issledovaniiakb: A monograph based on the proceedings 
of the International research seminar / ed. and comp. by V. S. Makarov, N. V. Zakharov and B. N. Gaydin. Moscow, Moscow University for the Humanities Publ. 238 p. Pp. 68-78. (In Russ.)

Korchevskiy, A. A. (2015b) «Znakomo i neozhidanno». Sovremennaia dramaturgiia, no. 3, p. 210. (In Russ.)

Lisovich, I. I. and Makarov, V. S. (2014) Nauchno-issledovatel'skii proekt «Virtual'naia shekspirosfera: transformatsii shekspirovskogo mifa v sovremennoi kul'ture». Znanie. Ponimanie. Umenie, no. 2, pp. 264-282. (In Russ.)

Lukov, Vl. A. (2006a) Kul't Shekspira: vvedenie v issledovanie. In: Shekspirovskie shtudii II: «Russkii Shekspir»: Studies and materials of the seminar, April 26, 2006. Moscow, Moscow University for the Humanities Publ. Pp. 3-11. (In Russ.)

Lukov, Vl. A. (2006b) Kul't Shekspira: tezaurusnyi analiz poniatiia. In: Literatura Velikobritanii $i$ romanskii mir: Paper abstracts of the International conference and the 26th Congress of Anglicists, September 19-22, 2006. Veliky Novgorod, Novgorod State University. Pp. 81-82. (In Russ.)

Lukov, Vl. A. (2006c) Kul't Shekspira kak nauchnaia problema. Vestnik Mezbdunarodnoi akademii nauk (Russkaia sektsiia), no. 2, pp. 70-72. (In Russ.)

Lukov, Vl. A. and Zakharov, N. V. (2008) Kul't Shekspira. Znanie. Ponimanie. Umenie, no. 1, pp. 132-141. (In Russ.)

Lewis, C. S. (2016) Novoe znanie i novoe nevezhestvo (iz knigi «Angliiskaia literatura XVI veka, za iskliucheniem dramy») / transl. by D. A. Ivanov. Inostrannaia literatura, no. 5, pp. 6-35. (In Russ.)

Lewis, W. (2016) Lev i lis : fragmenty knigi / transl. and introduction by T. Ya. Kazavchinskaia. Inostrannaia literatura, no. 5, pp. 84-90. (In Russ.)

Makarov, V. S. (2012) Unikal'nyi proekt Oxford University Press. Informatsionno-issledovatel'skaia baza dannykb "Sovremenniki Shekspira", February 20. [online] Available at: http://around-shake.ru/news/3764.htm (accessed 30.11.2016). (In Russ.)

Makarov, V. S., Zakharov, N. V. and Gaydin, B. N. (2015) Shekspir v mezhdistsiplinarnykh gumanitarnykh issledovaniiakh: itogi pervogo goda seminara. Informatsionnyi gumanitarnyi portal "Znanie. Ponimanie. Umenie", no. 6 (November - December), pp. 38-55. [online] Available at: http://zpu-journal.ru/e-zpu/2015/6/Makarov_Zakharov_Gaydin_Shakespeare-InterdisciplinaryHumanities-Research/ (accessed 30.11.2016). (In Russ.)

Mantel, H. (2016) Pis'mo Shekspiru / transl. by T. Ya. Kazavchinskaia. Inostrannaia literatura, no. 10, pp. 136-137. (In Russ.)

Mazer, C. (2016) Velikii datchanin : s Kennetom Branoi beseduet Kerri Meizer / C. Mazer (corr.), K. Branagh ; transl. by E. Malysheva. Inostrannaia literatura, no. 10, pp. 174-179. (In Russ.)

Auster, P. (2016) Smert' sera Uoltera Reli : rasskaz / transl. and introduction by A. V. Nesterov. Inostrannaia literatura, no. 5, pp. 61-67. (In Russ.)

Pervushina, E. A. (2016) Pamiati Ignatiia Mikhailovicha Ivanovskogo. Informatsionno-issledovatel'skaia baza dannykh “Russkii Shekspir”, October 7 [online] Available at: http://russhake.ru/menu/news/14055.html (accessed 30.11.2016). (In Russ.)

Plutzik, H. (2016) Goratsio : poema (Glava V. Karl : otryvok) / transl. and introduction by A. V. Nesterov. Inostrannaia literatura, no. 10, pp. 180-186. (In Russ.)

Poplavskiy, V. R. (2016) Zhanr shekspirovskogo «Gamleta» v rossiiskikh postanovkakh vtoroi poloviny XX veka. Inostrannaia literatura, no. 5, pp. 158-162. (In Russ.)

Radlov, S. D. (2016) O Polnom sobranii sochinenii Shekspira : proekt Universitetskogo izdatel'skogo konsortsiuma, Sankt-Peterburg. Inostrannaia literatura, no. 5, pp. 284-300. (In Russ.)

Roe, J. (2016) Shekspir i Makiavelli : fragment knigi / transl. by T. Ya. Kazavchinskaia. Inostrannaia literatura, no. 5, pp. 96-105. (In Russ.)

Ulyanov, N. (1998) Novyi Gamlet. Znanie - sila, no. 2, pp. 148-152. (In Russ.)

Fantasticheskii Shekspir (2016) : A collection / comp. by. V. Balashova, ed. by D. Volodikhin. Sevastopol, Shiko-Sevastopol' Publ. 182 p. (Series: Antologiia MiFa). (In Russ.) 
Hurley, D. (2016) Makiavelli i ego idei v p'esakh Shekspira : fragmenty lektsii, prochitannoi v Khirosime, aprel' 2009 / transl. by T. Ya. Kazavchinskaia. Inostrannaia literatura, no. 5, pp. 91-95. (In Russ.)

Chernaik, W. (2016) Vstuplenie k istoricheskim p'esam Shekspira : fragmenty knigi / transl. by T. Ya. Kazavchinskaia. Inostrannaia literatura, no. 5, pp. 72-83. (In Russ.)

Shekspir $v$ mezhdistsiplinarnykh gumanitarnykb issledovaniiakb (2015) : A monograph based on the proceedings of the International research seminar / ed. and comp. by V. S. Makarov, N. V. Za-kharov and B. N. Gaydin. Moscow, Moscow University for the Humanities Publ. 238 p. (In Russ.)

Shakespeare, W. (2015) Tragicheskaia istoriia Gamleta, printsa Datskogo. Pervoe kvarto / transl. by. A. A. Korchevskiy. Sovremennaia dramaturgiia, no. 3, pp. 211-234. (In Russ.)

Shakespeare, W. (2016a) Venera i Adonis : poema : s parallel'nym angliiskim tekstom / transl. by V. A. Kulle. Inostrannaia literatura, no. 10, pp. 138-157. (In Russ.)

Shakespeare, W. (2016b) Tragicheskaia istoriia Gamleta, printsa Datskogo. Pervoe kvarto (1603) / transl. and foreword by A. A. Korchevskiy, afterword by M. D. Litvinova. Moscow, Tekst Publ. 272 p. (In Russ.)

Shakespeare, W. (2016c) Sonety/ prepared by A. N. Gorbunov, V. S. Makarov, E. A. Pervushina, V. S. Florova and E. V. Haltrin-Khalturina ; ed. by A. N. Gorbunov. Moscow, Nauka Publ. (Series: Literaturnye pamiatniki). (In Russ.)

Shakespeare, W. and Fletcher, J. (2016) Dvoinoe verolomstvo, ili Vliublennye v bede : v redaktsii L'iuisa Teobal'da / transl. by A. A. Korchevskiy. Sovremennaia dramaturgiia, no. 3, pp. 212-235. (In Russ.)

Alberge, D. (2016) Christopher Marlowe credited as one of Shakespeare's co-writers. The Guardian, October 23. [online] Available at: https://theguardian.com/culture/2016/oct/23/christopher-marlowe-credited-as-one-of-shakespeares-co-writers (accessed 30.11.2016).

Arendt, H. (1951) The origins of totalitarianism. New York, Harcourt, Brace and Co. xv, 477 p.

Brown, M. (2016) Shakespeare more popular abroad than in Britain, study finds. The Guardian, April 19. [online] Available at: https://theguardian.com/culture/2016/apr/19/shakespeare-popularchina-mexico-turkey-than-uk-british-council-survey (accessed 30.11.2016).

Dobson, M. (2016) Shakespeare, not the national poet. University of Birmingham [online] Available at: http://birmingham.ac.uk/research/perspective/shakespeare.aspx (accessed 30.11.2016).

Donaldson, A. (2016) All the world's: How Shakespeare is viewed around the globe and the role bis work can play to support the UK's soft power / ed. by M. Lotten. S. n., British Council. 41 p.

Furness, H. (2016) Four in ten Brits don't like or understand Shakespeare. The Telegraph, April 19. [online] Available at: http://telegraph.co.uk/news/2016/04/18/four-in-ten-brits-dont-like-or-understand-shakespeare/ (accessed 30.11.2016).

Greenblatt, S. (1980) Renaissance self-fashioning: From More to Shakespeare. Chicago, University of Chicago Press. $321 \mathrm{p}$.

Greenblatt, S. (1988) Shakespearean negotiations: The circulation of social energy in Renaissance England. Berkeley, CA, University of California Press. xi, 205 p.

Greenblatt, S. (2002) Hamlet in purgatory. Princeton, NJ, Princeton University Press. xii, 322 p.

Greenblatt, S. (2004) Will in the world: How Shakespeare became Shakespeare. New York, W. W. Norton. 430 p.

Greenblatt, S. (2010) Shakespeare's freedom. Chicago ; London, The University of Chicago Press. xiii, $144 \mathrm{p}$.

Greene, R. (1905) The plays \& poems of Robert Greene : in 2 vols. / ed., with introductions and notes, by J. Churton Collins. Oxford, Clarendon Press.

Hoffman, C. (1955) The man who was Shakespeare. London, M. Parrish. 256 p.

Neckermann, C. N. (2016) Spooky Shakespeare HarvardX course debuts on Halloween. The Harvard Crimson, October 31. [online] Available at: https://thecrimson.com/article/2016/10/31/ shakespeare-harvardx-hamlet-course-debut/ (accessed 30.11.2016). 
Palfrey, S. and Smith, E. (2016) Shakespeare’s dead. Oxford, Bodleian Library. 191 p.

Rielly, B. (2016) The unkindest cut? Shakespeare more popular abroad than in Britain. Daily Mail Online, April 19. [online] Available at: http://dailymail.co.uk/wires/reuters/article-3547902/Theunkindest-cut-Shakespeare-popular-abroad-Britain.html (accessed 30.11.2016).

Sams, E. (1995) The real Shakespeare: Retrieving the early years, 1564-1594. New Haven, CT, Yale University Press. xvi, 256 p.

Schmitt, C. (2009) Hamlet or Hecuba: The intrusion of the time into the play. New York, Telos Press Publishing. li, 119 p.

Shakespeare, W. (2002) The complete sonnets and poems / ed. by. C. Burrow. Oxford ; New York, Oxford University Press. ix, 750 p. (Oxford World's Classics).

Tarlinskaja, M. (2014) Shakespeare and the versification of English drama, 1561-1642. Farnham, Surrey ; Burlington, VT, Ashgate. x, 411 p.

Taylor, G. (2016) General editors' preface / G. Taylor, J. Jowett, T. Bourus and G. Egan. In: The new Oxford Shakespeare. Modern critical edition: The complete works / ed. by G. Taylor, J. Jowett, T. Bourus and G. Egan. Oxford University Press. Pp. iv-vi.

Taylor, G. and Bourus, T. (2016a) Why read this complete works? In: The new Oxford Shakespeare. Modern critical edition: The complete works / ed. by G. Taylor, J. Jowett, T. Bourus and G. Egan. Oxford University Press. Pp. 45-58.

Taylor, G. and Bourus, T. (2016b) Why read Shakespeare's complete works? In: The new Oxford Shakespeare. Modern critical edition: The complete works / ed. by G. Taylor, J. Jowett, T. Bourus and G. Egan. Oxford University Press. Pp. 1-44.

The Cambridge guide to the worlds of Shakespeare (2016) : in 2 vols. / ed. by B. R. Smith and K. Rowe. New York, Cambridge University Press. Vol. 2: The world's Shakespeare, 1660 - present. xvii, $998 \mathrm{p}$.

The creation and re-creation of Cardenio: Performing Shakespeare, transforming Cervantes (2013) / ed. by T. Bourus and G. Taylor. New York, Palgrave Macmillan. xviii, 329 p.

The quest for Cardenio: Shakespeare, Fletcher, Cervantes, and the lost play (2012) / ed. by D. Carnegie and G. Taylor. Oxford, Oxford University Press. xiv, 420 p.

The Shakespeare circle: An alternative biograpby (2015) / ed. by P. Edmondson and S. Wells. Cambridge, Cambridge University Press. ix, 358 p.

Walker-Wraight, A. D. (1994) The story that the sonnets tell. London, Adam Hart. vi, 585 p.

Wells, S. (2003) Shakespeare: For all time. Oxford ; New York, Oxford University Press. xxi, $442 \mathrm{p}$.

Wells, S. (2006) Shakespeare \& Co. : Christopher Marlowe, Thomas Dekker, Ben Jobnson, Thomas Middleton, John Fletcher and the other players in his story. London, Allen Lane. xv, 285 p.

Submissiondate: 7.12 .2016$.

Макаров Владимир Сергеевич - кандидат филологических наук, доцент кафедры германской филологии Православного Свято-Тихоновского гуманитарного университета. Адрес: 109651, г. Москва, ул. Иловайская, д. 9, стр. 2, комн. 304. Тел.: +7 (495) 646-71-38. Эл. адрес: mail @vmakarov.name

Захаров Николай Владимирович - доктор философии (PhD), кандидат филологических наук, директор Центра теории и истории культуры Института фундаментальных и прикладных исследований Московского гуманитарного университета, ученый секретарь Шекспировской комиссии РАН. Адрес: 111395, Россия, г. Москва, ул. Юности, д. 5, корп. 6. Тел.: +7 (499) 374-75-95. Эл. адрес: nikoltine@yandex.ru

Гайдин Борис Николаевич - кандидат философских наук, заместитель директора Центра теории и истории культуры Института фундаментальных и прикладных исследований Московского гуманитарного университета. Адрес: 111395, Россия, г. Москва, ул. Юности, д. 5, корп. 6. Тел.: +7 (499) 374-59-30. Эл. алрес: bngaydin@mosgu.ru 
Makarov Vladimir Sergeevich, Candidate of Philology, Associate Professor, Department of Germanic Philology, St. Tikhon Orthodox University for the Humanities. Postal address: R. 305, Bldg. 2, 9 Ilovaiskaya St., 109651 Moscow, Russian Federation. Tel.: +7 (495) 646-71-38. E-mail: mail@ vmakarov.name

Zakharov Nikolay Vladimirovich, PhD, Candidate of Philology, Director, Center for Theory and History of Culture, Institute of Fundamental and Applied Studies, Moscow University for the Humanities; Full member, International Academy of Sciences; Academic Secretary, Shakespeare Committee, Russian Academy of Sciences. Postal address: Bldg. 6, 5 Yunosti St., Moscow, Russian Federation, 111395.Tel.+7 (499) 374-75-95.E-mail:nikoltine@yandex.ru

Gaydin Boris Nikolaevich, Candidate of Philosophy, Deputy Director, Center for the Theory and History of Culture, Institute of Fundamental and Applied Studies, Moscow University for the Humanities. Postal address: Bldg. 6, 5 Yunosti St., Moscow, Russian Federation, 111395. Tel.: +7 (499) 374-59-30. E-mail: bngaydin@mosgu.ru 